\title{
Penerapan Modifiksi Alat Bantu Pembelajaran Bokortasko terhadap Hasil Belajar Permainan Bulutangkis Siswa Kelas VIII A di SMPN 18 Kota Jambi Tahun 2017/2018
}

\author{
Bambang ${ }^{1}$
}

\begin{abstract}
Abstrak: Kurangnya keterlibatan siswa dalam mengikuti pembelajaran pendidikan jasmani yang mengakibatkan hasil belajar menjadi kurang, perlu dilakukan suatu tindakan yang mampu meningkatkan partisipasi siswa sehingga tujuan dari pembelajaran dapat dicapai. tujuan dari penelitian ini adalah untuk mengetahui peningkatan hasil belajar permainan bulutangkis pada siswa kelas VIII A melalui penerapan modifikasi alat bantu pembelajaran bokortasko di SMPN 18 Kota Jambi tahun ajaran 2017/2018. Dalam penelitian ini rancangan penelitian yang digunakan adalah penelitian tindakan kelas (PTK) dengan dilakukan tindakan melalui siklus I dan siklus II. Hasil belajar kognitif mengalami peningkatan. Pada siklus I nilai rata-rata tes tertulis 7,8 dan pada siklus II nilai rata-rata tes tertulis 9, jadi hasil belajar kognitif dari siklus I ke siklus II mengalami peningkatan sebesar 15,4\%. Hasil belajar afektif juga mengalami peningkatan. Nilai rata-rata afektif pada siklus I adalah 7,9, dan nilai rata-rata afektif pada siklus II adalah 8,2. Jadi hasil belajar afektif dari siklus I ke siklus II mengalami peningkatan sebesar 3,8\%. Hasil belajar psikomotorik juga mengalami peningkatan, pada siklus I nilai rata-rata psikomotorik adalah 7,6 dan pada siklus II adalah 8,1. Jadi hasil belajar psikomotorik dari siklus I ke siklus II mengalami peningkatan sebesar 6,6\%.
\end{abstract}

Kata kunci: Modifikasi, Pembelajaran, Hasil

Abstract: Lack of student involvement in participating in physical education learning which results in learning outcomes becoming less, it is necessary to do an action that can increase student participation so that the goals of learning can be achieved. The purpose of this study was to determine the improvement in learning outcomes of badminton games in class VIII A students through the application of modifications to the bokortasko learning aids in Jambi City Middle School 18 of the academic year 2017/2018. In this study, the research design used was classroom action research (CAR) by taking action through cycle I and cycle II. Cognitive learning outcomes have increased. In the first cycle the average value of the written test was 7.8 and in the second cycle the average score of the written test was 9, so the cognitive learning results from cycle I to cycle II increased by 15.4\%. Affective learning outcomes also increase. The affective average value in cycle I is 7.9, and the affective average value in cycle II is 8.2. So affective learning outcomes from cycle I to cycle II have increased by 3.8\%. Psychomotor learning outcomes also increased, in the first cycle the psychomotor score was 7.6 and in the second cycle was 8.1. So psychomotor learning outcomes from cycle I to cycle II increased by $6.6 \%$.

Keywords: Modifications, Learning, Results

\section{PENDAHULUAN}

Pendidikan jasmani pada dasarnya merupakan pendidikan melalui aktivitas jasmani yang dijadikan sebagai media untuk mencapai perkembangan individu secara menyeluruh (Adang Suherman dan Yoyo Bahagia, 2000:1). Pendidikan jasmani pada hakikatnya adalah proses pendidikan yang memanfaatkan aktivitas fisik untuk menghasilkan perubahan dalam kualitas individu, baik dalam hal fisik, mental, serta emosional. Pendidikan jasmani memperlakukan anak sebagai sebuah kesatuan utuh, makhluk total, daripada hanya menganggapnya sebagai seseorang yang terpisah kualitas fisik dan mentalnya. Secara umum tujuan pendidikan jasmani dapat diklasifikasikan ke dalam empat kategori, yaitu:

1. Perkembangan fisik. Tujuan ini berhubungan dengan kemampuan melakukan aktivitas-aktivitas yang melibatkan kekuatan-kekuatan fisik dari berbagai organ tubuh seseorang (phsycal fitness).

2. Perkembangan gerak. Tujuan ini berhubungan dengan kemampuan melakuka gerak secara efektif, efisien, halus, indah, sempurna (skillful).

3. Perkembangan mental. Tujuan ini berhubungan dengan kemampuan berpikir dan mengintepretasikan keseluruhan pengetahuan tentang pendidikan jasmani kedalam lingkungannya sehingga memungkinkan tumbuh dan berkembangnya pengetahuan, sikap, dan tanggung jawab siswa. 
4. Perkembangan sosial. Tujuan ini berhubungan dengan kemampuan siswa dalam menyesuaikan diri pada suatu kelompok atau masyarakat (Adang Suherman dan Yoyo Bahagia, 2000:23)

Oleh karena itu pendidikan jasmani harus diutamakan mengingat mempunyai tujuan yang penting dalam proses pembelajaran. Namun demikian pelaksanaan pendidikan jasmani di sekolah terasa masih belum cukup memuaskan karena dalam proses pembelajaran yang berlangsung di sekolah kurang efektif, sehingga tujuan dari pendidikan jasmani serta hasil belajar yang dicapai menjadi kurang. Dalam menentukan strategi pembelajaran yang tepat, guru perlu mempertimbangkan karakteristik siswa dan bahan atau materi yang dipelajari sehingga menciptakan pembelajaran yang membuat siswa berpartisipasi aktif dalam pembelajaran serta dapat mencapai hasil belajar yang optimal. Bila dalam proses pembelajaran siswa penuh perhatian terhadap bahan yang dipelajari, maka hasil belajar akan meningkat. Sebab dengan minat dan perhatian, akan ada konsentrasi, sehingga hasil belajar akan lebih optimal dan tidak lekas lupa.

Persentase ketuntasan belajar pada materi permainan bulutangkis tahun pelajaran 2017/2018 dari 25 siswa sebesar $48 \%$ dengan 12 siswa yang mencapai Kriteria Ketuntasan Minimal (KKM) yang telah ditentukan yaitu 78. Siswa yang belum mencapai KKM sebanyak 13 siswa dengan persentase 52\%. Ratarata nilai hanya mencapai 77 . Besar jumlah rata-rata dan nilai siswa yang mendapat nilai dibawah 78 menjadi bukti kongkrit bahwa hasil belajar siswa-siswi kelas VIII A belum mencapai hasil ketuntasan belajar siswa yang telah ditentukan, yaitu dengan nilai 78 menunjukkan proses pembelajaran yang belum melibatkan siswa secara aktif, guru masih menjadi pusat pembelajaran, kurangnya model pembelajaran, gaya mengajar serta pemodifikasian dan media pembelajaran yang masih kurang untuk mencapai tujuan pendidikan. Kurangnya keterlibatan siswa dalam mengikuti pembelajaran pendidikan jasmani yang mengakibatkan hasil belajar menjadi kurang, perlu dilakukan suatu tindakan yang mampu meningkatkan partisipasi siswa sehingga tujuan dari pembelajaran dapat dicapai. Berikut daftar nilai mata pelajaran penjasorkes materi permainan bulu tangkis:

Tabel 1

Daftar Nilai Siswa Kelas VIII A Mata Pelajaran Penjasorkes Materi Permainan Bulutangkis Tahun Ajaran 2017/2018

\begin{tabular}{clcc}
\hline No & Nama & Nilai Akhir & Keterangan \\
\hline 1 & Adelia Ananda Putri & 78 & Tuntas \\
2 & Ananda Putri & 77 & Tidak Tuntas \\
3 & Andi Aminatul & 80 & Tuntas \\
4 & Desy Dwiriyani & 76 & Tidak Tuntas \\
5 & Dias Larasati & 80 & Tuntas \\
6 & Dinda Amaria & 77 & Tidak Tuntas \\
7 & Elman Pratama & 78 & Tuntas \\
8 & Fenni Wang & 74 & Tidak Tuntas \\
9 & Firenita Agustin & 78 & Tuntas \\
10 & Julio Agung & 80 & Tuntas \\
11 & Kayla Ashifa & 79 & Tuntas \\
12 & Laura Asmalinda & 80 & Tuntas \\
13 & Lestari Triana & 80 & Tuntas \\
14 & Letychia F & 72 & Tidak Tuntas \\
15 & M. Raffi & 80 & Tuntas \\
16 & Maisarah & 80 & Tuntas \\
17 & Muhammad Daffa & 75 & Tidak Tuntas \\
18 & Muthia Fauziyah & 74 & Tidak Tuntas \\
19 & Nabila Putri & 72 & Tidak Tuntas \\
20 & Nicholas & 78 & Tuntas \\
21 & Pinky Ariyanti & 80 & Tuntas \\
22 & Putri Julia & 78 & Tuntas \\
23 & Rahma Fitriyani & 70 & Tidak Tuntas \\
24 & Ratih Trisna & 72 & Tidak Tuntas \\
25 & Ratu Defina & 75 & Tidak Tuntas \\
& Jumlah & 192,3 & \\
\hline
\end{tabular}


Dalam memilih sebuah alat bantu pembelajaran, seorang guru juga harus mempertimbangkan tingkat keekonomisan media yang akan digunakan. Biaya yang digunakan harus seimbang dengan biaya pengeluaran seminimal mungkin tetapi memiliki banyak manfaat dan keunggulan dalam proses pembelajaran, materi yang diberikan juga harus sesuai dengan tingkat pemahaman siswa, dan sebaiknya menarik perhatian siswa.

Bokortasko adalah singkatan dari bola berekor dan kertas koran. Modifikasi alat bantu pembelajaran bokortasko merupakan suatu bentuk media pembelajaran yang dirancang peneliti dengan menggunakan bola berekor yang dapat dibuat dengan memanfaatkan bola kertas koran yang diikat menggunakan tali rafia berwarna sehingga membentuk ekor. Pembuatan alat bantu ini sangat mudah dan tidak memerlukan banyak biaya.Melalui modifikasi bokortasko ini, sebagai upaya untuk membantu siswa dalam mengikuti pembelajaran permainan bulutangkis dengan peraturan yang telah dimodifikasi. Dengan memanfaatkan media yang ada di sekitar sekolah serta biaya yang tidak terlalu mahal, maka guru pendidikan jasmani dapat membuat alat bantu pembelajaran bokortasko dalam jumlah yang disesuaikan dengan banyaknya jumlah siswa yang mengikuti pembelajaran.

Tujuan modifikasi pembelajaran permainan bulutangkis ini adalah agar siswa merasa senang dalam mengikuti pembelajaran. Dengan perasaan senang terhadap pembelajaran tersebut, maka akan membuat siswa menjadi aktif dan antusias dalam mengikuti pembelajaran serta lebih mudah menguasai materi yang diajarkan. Guru dalam mengajarkan permainan bulutangkis harus membuat rencana pelaksanaan pembelajaran yang menarik dan menyenangkan untuk siswa, serta peralatan, susunan kelompok, gerakan teknik dasar yang variatif sehingga membuat situasi pembelajaran yang lebih menyenangkan dalam proses pembelajaran bulutangkis.

Atas dasar latar belakang tersebut, tujuan dari penelitian ini adalah untuk mengetahui peningkatan hasil belajar permainan bulutangkis pada siswa kelas VIII A melalui penerapan modifikasi alat bantu pembelajaran bokortasko di SMPN 18 Kota Jambi tahun ajaran 2017/2018

\section{Kajian Pustaka \\ Hasil Belajar Siswa}

Hasil belajar merupakan perubahan perilaku yang diperoleh pembelajar setelah mengalami aktivitas belajar (Chatarina Tri Anni, dkk, 2007:5). Hasil belajar merupakan faktor yang sangat penting, karena hasil belajar mencerminkan kemampuan siswa dalam mempelajari suatu mata pelajaran. Bentuk dari hasil belajar biasanya ditunjukkan dengan nilai yang diberikan guru. Seperti yang diungkapkan oleh Rifa'i (2009:85), bahwa belajar merupakan perubahan perilaku yang diperoleh siswa setelah mengalami kegiatan belajar. Perolehan aspek-aspek perubahan perilaku tersebut bergantung pada apa yang dipelajari oleh siswa. Oleh karena itu, apabila siswa mempelajari pengetahuan tentang konsep, maka perubahan perilaku yang diperoleh adalah berupa penguasaan konsep.

Bloom dalam Rifa'i (2009: 86), menyatakan bahwa hasil belajar meliputi tiga taksonomi yang disebut dengan ranah belajar. Diantaranya yaitu ranah kognitif (cognitive domain), ranah sikap (affective domain), dan ranah psikomotorik (psychomotoric domain). Rinciannya yaitu sebagai berikut:

1) Ranah kognitif. Berkaitan dengan hasil belajar berupa pengetahuan, kemampuan, dan kemahiran intelektual. Mencakup kategori pengetahuan, pemahaman, penerapan, analisis, sintesis, dan penilaian.

2) Ranah afektif. Berkaitan dengan hasil belajar berupa perasaan, sikap, minat, dan nilai. Mencakup kategori penerimaan, penanggapan, penilaian, pengorganisasian, dan pembentukan pola hidup.

3) Ranah psikomotor. Berkaitan dengan hasil belajar berupa kemampuan fisik seperti keterampilan motorik dan syaraf, manipulasi objek dan koordinasi syaraf. Kategori jenis perilaku untuk ranah psikomotorik yaitu persepsi, kesiapan, gerakan terbimbing, gerakan terbiasa, gerakan kompleks, penyesuaian, dan kreativitas.

Ketiga ranah tersebut menjadi objek penilaian hasil belajar. Di antara ketiga ranah, ranah kognitiflah yang banyak dinilai karena berkaitan dengan kemampuan siswa dalam menguasai isi bahan pembelajaran. Hasil belajar afektif dan psikomotorik juga harus menjadi bagian dari penilaian dalam proses pembelajaran di sekolah.

Dari pengertian-pengertian di atas, dapat disimpulkan bahwa hasil belajar adalah perubahan perilaku siswa dari tidak tahu menjadi tahu, dan dari tidak mengerti menjadi mengerti yang diukur menggunakan 
teknik penilaian tertentu setelah mengalami kegiatan belajar. Hasil belajar digunakan oleh guru untuk dijadikan patokan, ukuran, atau kriteria dalam mencapai suatu tujuan.

Hasil belajar mata pelajaran pendidikan jasmani olahraga dan kesehatan materi permainan bulutangkis yaitu berupa kemampuan kognitif yang dimiliki siswa yang dapat diketahui melalui tes formatif. Dan hasil belajar afektif dapat diperoleh melalui pengamatan terhadap aktivitas belajar siswa menggunakan lembar pengamatan aktivitas siswa. Serta hasil belajar psikomotorik siswa dapat diperoleh melalui tes ketrampilan/tes praktek.

\section{Karakteristik Perkembangan Anak Sekolah Menengah Pertama}

Tahap perkembangan anak pada masa sekolah menengah pertama masuk dalam pertumbuhan tahap IV, yaitu dengan karakteristik:

1) Karakteristik Jasmani:

a. Laki-laki ataupun putri ada pertumbuhan yang memanjang.

b. Membutuhkan pengaturan istirahat yang baik.

c. Sering menampilkan kecanggungan dan koordinasi yang kurang baik yang sering diperlihatkan.

d. Merasa mempunyai ketahanan dan sumber energi yang tidak terbatas.

e. Mudah lelah, tetapi tidak dihiraukan.

f. Mengalami pertumbuhan dan perkembangan yang sangat cepat.

g. Anak laki-laki mempunyai kecepatan dan kekuatan otot yang lebih baik dari pada putri.

h. Kesiapan dan kematangan untuk keterampilan bermain menjadi baik.

2) Karakteristik Psikis atau mental:

a. Banyak mengeluarkan energi untuk fantasinya.

b. Ingin menentukan pandangan hidupnya.

c. Mudah gelisah karena keadaan yang remeh.

d. Ingin diakui oleh kelompoknya.

e. Mengetahui moral dan etik dari kebudayaannya.

f. Persekawanan yang tetap makin berkembang.

Keterampilan gerak telah siap diarahkan kepada permainan besar atau olahraga prestasi. Bentuk penyajian pembelajaran sebaiknya dalam bentuk bermain beregu, komando, tugas dan lomba. Perlu diketahui, bahwa untuk keperluan fantasi dan imajinasinya, kecepatan tumbuh serta kematangan sejenisnya banyak dibutuhkan energi dalam jumlah besar, maka terjadilah kemerosotan jasmani atau psikik. Keadaan anak pada masa pertumbuhan dan kematangan terjadi kemurungan dan fantasi yang berlebihan. Keadaan ini menyebabkan rasa tidak mampu, enggan bergerak dan mengelak terhadap pelajaran pendidikan jasmani. Oleh sebab itu, perlu dipikirkan pemberian jenis permainan yang rekreatif (Sukintaka, 1992:45).

\section{Pengertian Alat Bantu Pembelajaran}

Alat bantu merupakan alat-alat yang digunakan oleh pendidik dalam menyampaikan materi pembelajaran. Alat bantu ini lebih sering disebut alat peraga karena berfungsi untuk membantu dan mempraktekkan sesuatu dalam proses pendidikan pengajaran. Jelas pula pengertian atau pengetahuan yang diperoleh. Dengan perkataan lain, alat peraga ini dimaksudkan untuk mengerahkan indera sebanyak mungkin suatu objek, sehingga mempermudah persepsi. Manfaat alat bantu pembelajaran menurut Soekidjo (2003) dalam Agus Kristiyanto (2010:129) secara terperinci manfaat alat peraga antara lain: 1) menimbulkan minat sasaran pendidikan, 2) mencapai sasaran yang lebih banyak, 3) membantu mengatasi hambatan bahasa, 4) merangsang sasaran pendidikan untuk melaksanakan pesan-pesan kesehatan, 5) membantu sasaran pendidikan untuk belajar lebih banyak dan cepat, 6) merangsang sasaran pendidikan untuk meneruskan pesan-pesan yang diterima kepada orang lain, 7) mempermudah penyampaian bahan pendidikan/informasi oleh para pendidik pelaku pendidikan, dan 8) mempermudah penerimaan informasi oleh sasaran pendidikan.

Ada beberapa faktor dan kriteria yang perlu diperhatikan dalam memilih alat bantu:

1. Objektivitas. Unsur subjektivitas guru di dalam memilih media pengajaran harus dihindari. Artinya, guru tidak boleh memilih suatu media pengajaran atas dasar kesenangan pribadi. Apabila 
secara objektif, berdasarkan hasil penelitian atau percobaan, suatu media pengajaran menunjukkan keefektifan dan efisiensi yang tinggi, maka guru jangan merasa bosan menggunakannya. Untuk menghindari pengaruh unsur subjektivitas guru, alangkah baiknya di dalam memilih media pengajaran itu guru meminta pandangan atau saran dari teman sejawat dan atau melibatkan siswa.

2. Program Pengajaran. Program pengajaran yang akan disampaikan kepada anak didik harus sesuai dengan kurikulum yang berlaku, baik isinya, strukturnya, maupun kedalamannya. Meskipun secara teknis program tersebut sangat baik, jika tidak sesuai dengan kurikulum ia tidak akan banyak membawa manfaat, bahkan mungkin hanya menambah beban baik bagi anak didik maupun bagi guru di samping akan membuang-buang waktu, tenaga dan biaya. Terkecuali jika program itu hanya dimaksudkan untuk mengisi waktu senggang saja, daripada anak didik bermain-main tidak karuan.

3. Sasaran Program. Sasaran program yang dimaksud adalah anak didik yang akan menerima informasi pengajaran melalui media pengajaran. Pada tingkat usia tertentu dan dalam kondisi tertentu anak didik mempunyai kemampuan tertentu pula, baik cara berpikirnya, daya imajinasinya, kebutuhannya, maupun daya tahan dalam belajarnya. Untuk itu maka media yang akan digunakan harus dilihat kesesuaiannya dengan tingkat perkembangan anak didik, baik dari segi bahasa, simbol-simbol yang digunakan, cara dan kecepatan penyajiannya, ataupun waktu penggunaanya.

4. Situasi dan Kondisi. Situasi dan kondisi yang ada juga perlu mendapat perhatian di dalam menentukan pilihan media pengajaran yang akan digunakan. Situasi dan kondisi yang dimaksud meliputi (1) situasi dan kondisi sekolah atau tempat dan ruangan yang akan dipergunakan, seperti ukurannya, perlengkapannya, ventilasinya, dan (2) situasi serta kondisi anak didik yang akan mengikuti pelajaran mengenai jumlahnya, motivasi dan kegairahannya. Anak didik yang sudah melakukan praktik yang berat, seperti praktik olahraga, biasanya kegairahan belajarnya sangat menurun.

5. Kualitas Teknik. Dari segi teknik, media pengajaran yang akan digunakan perlu diperhatikan, apakah sudah memenuhi syarat. Barangkali ada rekaman audionya atau gambar-gambar atau alat-alat bantunya yang kurang jelas atau kurang lengkap, sehingga perlu penyempurnaan sebelum digunakan. Suara atau gambar yang kurang jelas bukan saja tidak menarik tetapi juga dapat mengganggu jalannya proses belajar dan mengajar.

6. Keefektifan dan Efisiensi Penggunaan. Keefektifan berkenaan dengan hasil yang dicapai, sedangkan efisiensi berkenaan dengan proses pencapaian hasil pencapaian tersebut. Keefektifan dalam penggunaan media meliputi apakah dengan menggunakan media tersebut informasi pengajaran dapat diserap dengan optimal oleh anak didik sehingga menimbulkan perubahan tingkah lakunya. Sedangkan efisiensi meliputi apakah dengan menggunakan media tersebut, waktu, tenaga, dan biaya yang dikeluarkan untuk mencapai tujuan tersebut sedikit mungkin. Ada media yang dipandang sangat efektif untuk mencapai suatu tujuan, namun proses pencapaiannya tidak efisien, baik dalam pengadaannya maupun penggunaannya. Demikian pula sebaliknya, ada media yang efisien dalam penggunaan dan pengadaannya, namun tidak efektif dalam pencapaian hasilnya. Memang sangat sulit untuk mempertahankan keduanya (efektif dan efisien) secara bersamaan, tetapi memilih media (alat bantu) pengajaran guru sedapat mungkin memenuhi keefektifan dan keefisiensian penggunaannya (Syaiful Bahri Djamarah, 2010:215-217).

\section{Pengertian Pendidikan Jasmani}

Pendidikan Jasmani merupakan usaha pendidikan dengan menggunakan aktivitas otot-otot besar hingga proses pendidikan yang berlangsung tidak terhambat oleh gangguan kesehatan dan pertumbuhan badan. Sebagai bagian integral dari proses pendidikan secara keseluruhan, pendidikan jasmani merupakan usaha yang bertujuan untuk mengembangkan kawasan organik, neuromuskuler, intelektual, dan sosial (H Abdulkadir Ateng, 1992:4). Sharman (1936) dalam Nadisah (1992) mengemukakan bahwa pendidikan jasmani adalah bagian dari pendidikan (secara umum) yang berlangsung melalui aktivitas yang melibatkan mekanisme gerak tubuh manusia dan menghasilkan pola-pola perilaku pada individu yang bersangkutan. Pendidikan jasmani pada dasarnya merupakan pendidikan melalui aktivitas jasmani yang dijadikan sebagai media untuk mencapai perkembangan individu secara menyeluruh (Adang Suherman, 2000:1). 
Pendidikan jasmani pada hakikatnya adalah proses pendidikan yang memanfaatkan aktivitas fisik untuk menghasilkan perubahan dalam kualitas individu, baik dalam hal fisik, mental, serta emosional. Pendidikan jasmani memperlakukan anak sebagai sebuah kesatuan utuh, makhluk total, daripada hanya menganggapnya sebagai seseorang yang terpisah kualitas fisik dan mentalnya. Agar dalam pelaksanaan pendidikan jasmani dapat berjalan dengan baik, maka seorang guru harus bisa menjadi seorang pendidik dan pengajar yang baik dalam mencapai sasaran yang diinginkan. Dalam PP nomor 19 tahun 2005 tentang Standar Nasional Pendidikan pasal 6 ayat (1): "kelompok mata pelajaran jasmani pada SMP/MTs/SMPLB dimaksudkan untuk meningkatkan potensi serta membudayakan sportivitas dan kesadaran hidup sehat." Oleh karena itu, pelaksanaan pendidikan jasmani harus diarahkan pada pencapaian tujuan tersebut.

Menurut permendiknas No. 23 Tahun 2006 tentang Standar Kompetensi Kelulusan untuk Satuan Pendidikan Dasar dan Menengah adalah sebagai berikut:

1) Permainan dan olahraga meliputi : olahraga tradisional, permainan eksplorasi gerak, ketrampilan lokomotor non-lokomotor, dan manipulasi, atletik, kasti, rounders, kippers, sepak bola, bola basket, bola voli, tenis meja, tenis lapangan, bulutangkis dan bela diri, serta aktivitas lainnya.

2) Aktivitas pengembangan meliputi : mekanika sikap tubuh, komponen kebugaran jasmani, dan bentuk postur tubuh, serta aktivitas lainnya.

3) Aktivitas uji diri / senam meliputi : ketangkasan sederhana, ketangkasan tanpa alat, ketangkasan dengan alat, dan senam lantai, serta aktivitas lainnya.

4) Aktivitas ritmik meliputi : gerak bebas, senam pagi, SKJdan senam aerobikserta aktivitas lainnya.

5) Aktivitas air meliputi : permainan di air, keselamatan air, ketrampilan bergerak di air.

6) Pendidikan luar kelas meliputi : piknik / karya wisata, pengenalan lingkungan, berkemah, menjelajah dan mendaki gunung.

7) Kesehatan meliputi : penanaman budaya hidup sehat dalam kehidupan sehari- hari, khususnya yang terkait dengan perawatan tubuh agar tetap sehat,merawat lingkungan yang sehat, memilih makanan dan minuman yang sehat, mencegah dan merawat cedera, mengatur istirahat yang tepat dan berperan aktif dalam kegiatan P3K dan UKS.

Secara umum tujuan pendidikan jasmani dapat diklasifikasikan ke dalam empat kategori, yaitu:

1) Perkembangan fisik. Tujuan ini berhubungan dengan kemampuan melakukan aktivitas-aktivitas yang melibatkan kekuatan-kekuatan fisik dari berbagai organ tubuh seseorang (phsycal fitness).

2) Perkembangan gerak. Tujuan ini berhubungan dengan kemampuan melakukan gerak secara efektif, efisien, halus, indah, sempurna (skillful).

3) Perkembangan mental. Tujuan ini berhubungan dengan kemampuan berpikir dan mengintepretasikan keseluruhan pengetahuan tentang pendidikan jasmani ke dalam lingkungannya sehingga memungkinkan tumbuh dan berkembangnya pengetahuan, sikap, dan tanggung jawab siswa.

4) Perkembangan sosial. Tujuan ini berhubungan dengan kemampuan siswa dalam menyesuaikan diri pada suatu kelompok atau masyarakat (Adang Suherman, 2000:23).

\section{Pengertian Modifikasi}

Yang dimaksud dengan modifikasi itu ialah pengurangan atau penggantian unsur-unsur tertentu (Supandi, 1992:107). Modifikasi merupakan salah satu usaha yang dapat dilakukan oleh para guru agar pembelajaran mencerminkan DAP (Developmentally Apropriate Practice). Oleh karena itu, DAP termasuk di dalamnya "body scaling" atau ukuran tubuh siswa, harus selalu dijadikan prinsip utama dalam memodifikasi pembelajaran penjas. Esensi modifikasi adalah menganalisa sekaligus mengembangkan materi pelajaran dengan cara meruntunkannya dalam bentuk aktivitas belajar yang potensial dapat memperlancar siswa dalam belajarnya. Cara ini dimaksudkan untuk menuntun, mengarahkan dan membelajarkan siswa dari yang tadinya tidak bisa menjadi bisa, dari tingkat yang tadinya lebih rendah menjadi tingkat yang lebih tinggi (Adang Suherman dan Yoyo Bahagia, 2000:1)

Modifikasi pembelajaran dapat dikaitkan dengan kondisi lingkungan pembelajarannya. Modifikasi lingkungan pembelajaran ini dapat diklarifikasikan ke dalam beberapa klasifikasi seperti yang diuraikan di bawah ini: 
1) Peralatan. Guru dapat mengurangi atau menambah tingkat komfleksitas dan kesulitan tugas ajar dengan cara memodifikasi peralatan yang digunakan untuk melakukan skill itu. Misalnya, berat-ringannya, besarkecilnya, tinggi- rendahnya, panjang-pendeknya peralatan yang digunakan

2) Penataan ruang gerak dalam berlatih. Guru dapat mengurangi atau menambah tingkat komfleksitas dan kesulitan tugas ajar dengan cara menata ruang gerak siswa dalam berlatih. Misal, dribbling, pas bawah, atau lempar-tangkap di tempat, bermain di ruang kecil atau besar

3) Jumlah siswa yang terlibat. Guru dapat mengurangi atau menambah tingkat komfleksitas dan kesulitan tugas ajar dengan cara mengurangi atau menambah jumlah siswa yang terlibat dalam melakukan tugas ajar. Misal: belajar pas bawah sendiri, berpasangan, bertiga, berempat, dan seterusnya.

4) Organisasi atau formasi berlatih. Formasi belajar juga dapat dimodifikasi agar lebih berorientasi pada curahan waktu aktif belajar. Usahakan agar informasi formasi tidak banyak menyita waktu namun masih tetap memperhatikan produktifitas belajar dan tingkat perkembangan belajar siswanya. Formasi formal, kalau belum dikenal siswa, biasanya cukup banyak menyita waktu sehingga waktu aktif belajarnya berkurang. Formasi berlatih ini sangat banyak ragamnya tergantung kreativitas guru (Adang Suherman dan Yoyo Bahagia, 2000:7-8).

\section{Bulutangkis}

Permainan bulutangkis merupakan permainan yang bersifat individual, dan dapat dilakukan dengan cara satu orang melawan satu orang, atau dua orang melawan dua orang. Permainan ini menggunakan raket sebagai alat pemukul dan shuttlecock sebagai obyek yang dipukul. Lapangan permainan berbentuk segi empat dan dibatasi oleh net untuk memisahkan antara dua daerah, masing-masing daerah permainan sendiri dan daerah permainan lawan. Tujuan permainan adalah berusaha untuk menjatuhkan kok di daerah lawan dan berusaha agar lawan tidak dapat memukul kembali kok atau terpaksa jatuh di daerah permainan sendiri. Pada saat permainan berlangsung, masing- masing pemain berusaha memukul sebelum kok menyentuh lantai di daerah permainan sendiri. Apabila kok jatuh di lantai atau menyangkut di net, maka permainan terhenti (Herman Subarjah, 2004:3).

Dalam setiap cabang olahraga memang secara khusus mempuyai fasilitas dan peraturan permainan tertentu. Oleh karena itu kiranya perlu disajikan macam- macam alat dan perlengkapan yang telah diatur dalam peraturan permainan bulutangkis. Uraian berikut berisi mengenai hal-hal tersebut diatas.

1) Lapangan. Ukuran lapangan bulutangkis adalah : panjang 13,4 m dan lebar 6,1 m. Lapangan berbentuk persegi panjang yang dibatasi oleh garis selebar $40 \mathrm{~mm}$. Garis harus mudah dilihat dan sebaiknya berwarna putih.

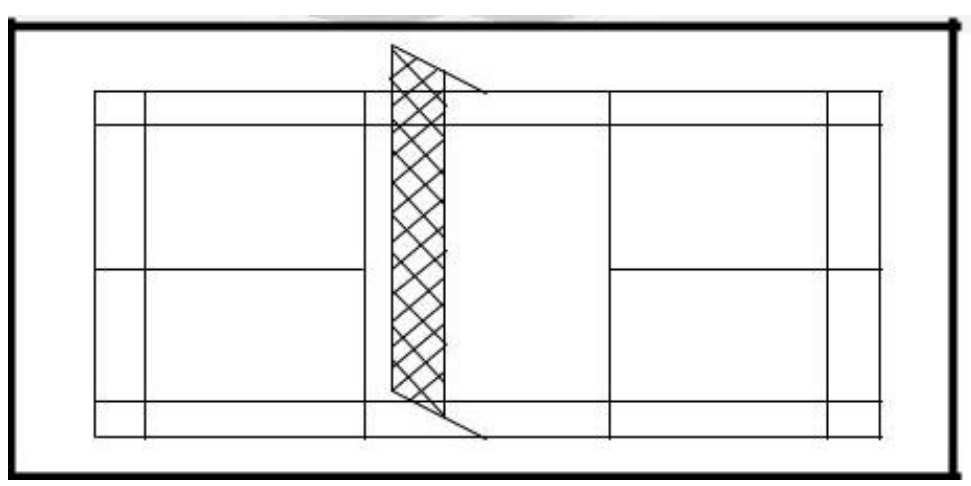

Gambar 1. Lapangan bulutangkis

2) Net, terbuat dari tali halus dan berwarna gelap, lubang-lubangnya berjarak antara 15-120 mm. Panjang net sebaiknya sesuai dengan lebar lapangan yaitu $6,10 \mathrm{~m}$ dan lebarnya $76 \mathrm{~cm}$ dengan bagian atasnya mempunyai pinggiran pita putih selebar 7,5 cm. Tinggi net yakni $155 \mathrm{~cm}$, bagian paling atas net di bagian tengah berjarak 1,524 $\mathrm{m}$ dari lantai, pada pinggir lapangan berjarak 1,55 $\mathrm{m}$ dari garis permainan ganda. 


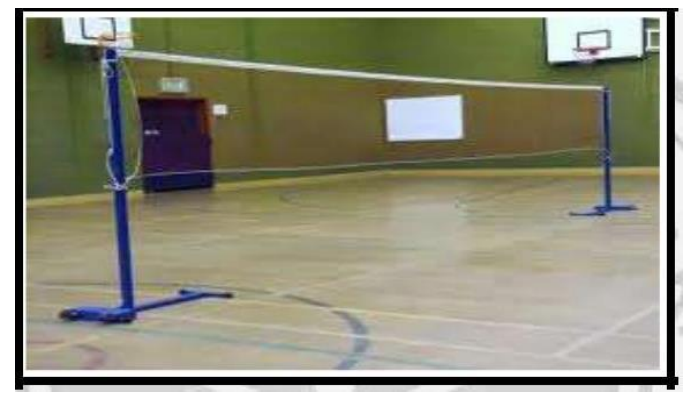

Gambar 2. Net Bulutangkis

3) Shuttlecock, terbuat dari bahan alami atau bahan sintesis dengan 16 lembar bulu yang ditancapkan pada gabus yang dilapisi kain atau kulit. Panjang Shuttlecock 64-74 mm. Berat Shuttlecock harus antara 4,74 gr - 5,50 gr. Diameter gabus harus antara $25 \mathrm{~mm}-28 \mathrm{~mm}$ dan dibulatkan pada bagian bawahnya.

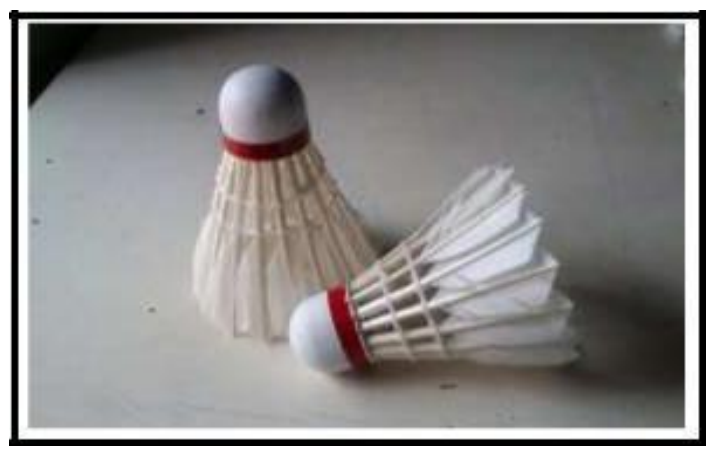

Gambar 3. Shuttlecock

4) Raket, Kerangka raket panjang keseluruhannya tidak boleh melebihi $680 \mathrm{~mm}$ dan lebar keseluruhan tidak boleh melebihi $230 \mathrm{~mm}$. Panjang keseluruhan area yang disenari tidak boleh melebihi $280 \mathrm{~mm}$ dan lebar keseluruhan tidak boleh melebihi $220 \mathrm{~mm}$

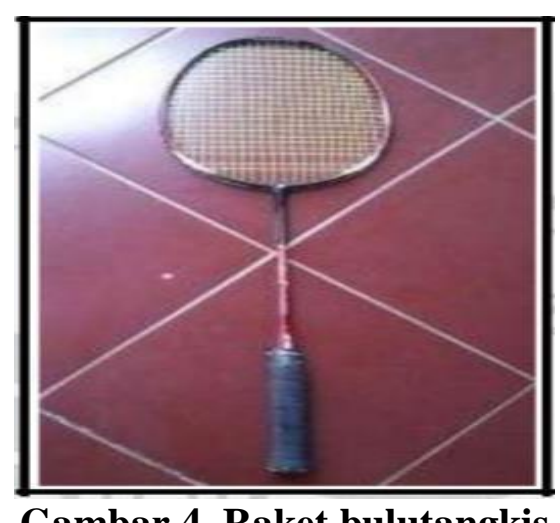

Gambar 4. Raket bulutangkis

\section{Hakekat Permainan Bokortasko}

Bokortasko adalah singkatan dari bola berekor dan kertas koran. Modifikasi alat bantu pembelajaran bokortasko merupakan suatu bentuk media pembelajaran yang dirancang peneliti dengan menggunakan bola berekor yang dibuat dengan memanfaatkan bola kertas koran yang diikat menggunakan tali rafia berwarna sehingga membentuk bola berekor. Pembuatan alat bantu ini sangat mudah dan tidak memerlukan banyak biaya. Tujuan dilaksanakannya pembelajaran menggunakan alat bantu pembelajaran bokortasko adalah: 1.) Meningkatkan keberanian siswa dalam melakukan unjuk kemampuan, 2.) Meningkatkan tanggung jawab siswa dengan memberikan suatu kepercayaan. 3.) Meningkatkan rasa sosial. 4.) Meningkatkan kerjasama antar siswa. 5.) Meningkatkan interaksi siswa. 6.) Memberikan 
suasana atau nuansa baru dalam pembelajaran. Uraian berikut berisi mengenai fasilitas permainan bokortasko:

1) Lapangan. Dalam pembelajaran, ukuran lapangan tidak dimodifikasi, hanya saja garis lapangan yang digunakan adalah garis tepi lapangan dan garis servis paling depan. Hal ini dilakukan untuk mempermudah siswa dalam melakukan pembelajaran bulutangkis melalui permainan bokortasko baik dalam melakukan pukulan maupun menempatkan posisi ketika bermain.

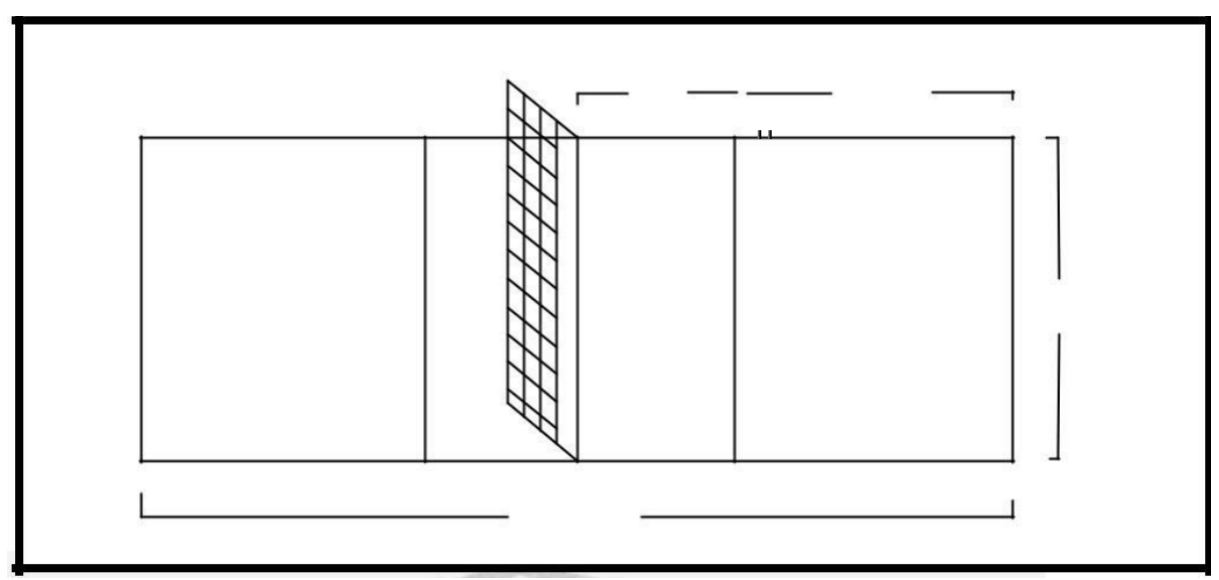

Gambar 5. Modifikasi lapangan bulutangkis

2) Net. Dalam pembelajaran bokortasko, tinggi dan ukuran net tidak dilakukan modifikasi dan menggunakan net yang sesungguhnya.

3) Bola berekor dan kertas Koran. Dalam modifikasi permainan ini, peneliti menggunakan bola kertas koran yang diikat dengan tali rafia berwarna sehingga membentuk bola berekor yang menarik ketika melayang di udara sebagai pengganti shuttlecock, hal ini dilakukan untuk menghemat biaya.

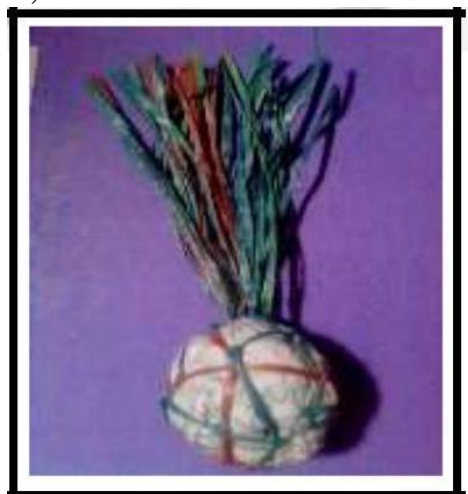

\section{Gambar 6. Bola kertas koran berekor}

4) Paddle, sebagai pengganti raket bulutangkis (alat pemukul), modifikasi alat permainan yang digunakan adalah paddle. Paddle tersebut terbuat dari kayu dengan ketebalan papan 8-12 mm, panjang keseluruhan 34-38 cm, dengan lebar papan 20-24 cm, panjang pegangan 10-12 cm dilengkapi dengan tali sebagai pengaman. Hal ini dilakukan karena di sekolah hanya mempunyai 2 buah raket dan 8 paddle. 


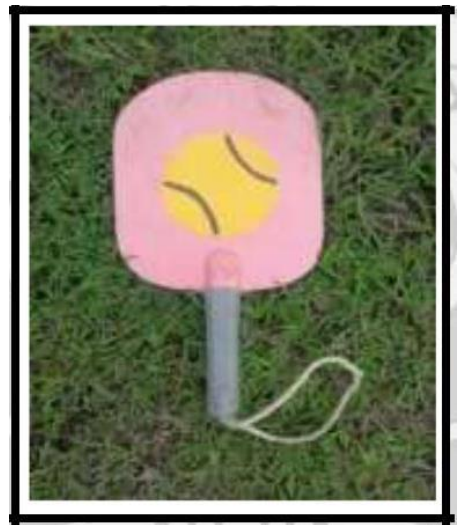

Gambar 7. Paddle

5) Pemain. Dalam pembelajaran ini dapat dimainkan 4 orang/kelompok. Hal ini dilakukan agar dalam pembelajaran melibatkan banyak siswa serta sesuai dengan kebutuhan lapangan dan peralatan yang digunakan.

6) Kardus, digunakan sebagai target sasaran ketika pembelajaran dengan menggunakan bola kertas koran dan bola berekor sedang berlangsung. Dengan memanfaatkan kardus sebagai target sasaran, maka siswa akan terpacu untuk memasukan bola ke dalam kardus, di samping itu tidak memerlukan biaya yang mahal. Kardus yang digunakan dalam pembelajaran dapat memanfaatkan kardus air mineral bekas yang layak pakai dengan ukuran panjang $35 \mathrm{~cm}$, lebar $25 \mathrm{~cm}$, dan tinggi $21 \mathrm{~cm}$. Maksud dari pemilihan kardus sebagai target sasaran adalah karena kardus air mineral tidak terlalu besar dan tidak terlalu kecil, sehingga sangat cocok untuk dijadikan target sasaran.

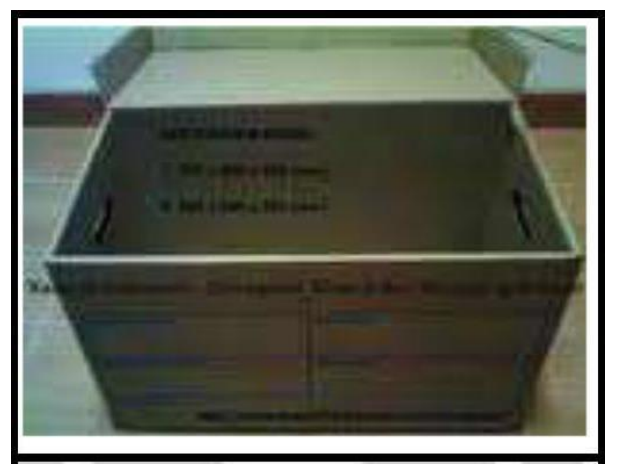

Gambar 8. Kardus

\section{METODE PENELITIAN}

Rancangan penelitian yang digunakan dalam penelitian ini adalah tindakan kelas dimana penelitiannya dilakukan oleh guru di dalam kelasnya sendiri melalui refleksi diri, dengan tujuan memperbaiki kinerjanya sebagai guru, sehingga hasil belajar siswa menjadi meningkat. Subjek dalam penelitian ini adalah siswa dan kelas VIII A SMPN 18 Kota Jambi dengan jumlah 25 siswa. Objek penelitian adalah hasil belajar permainan bulutangkis. Penelitian Tindakan Kelas (PTK) harus berkolaborasi dengan pihak lain. Pihak yang berkolaborasi adalah pihak-pihak yang secara riil menjadi komponen inti sesuai masalah dalam praktek pembelajaran atau kepelatihan olahraga yang diteliti. Kualitas PTK bahkan juga sangat bergantung dari kualitas kolaborator. Hal ini dapat dimaklumi karena siklus-siklus dalam PTK itu sangat mengandalkan kesepakatan antara peneliti dan kolaborator (Agus Kristiyanto, 2010:40). PTK terdiri atas empat tahap menurut Agus Kristiyanto (2010:55), yaitu planning (perencanaan), action (tindakan), observasi (pengamatan), reflection (refleksi). 


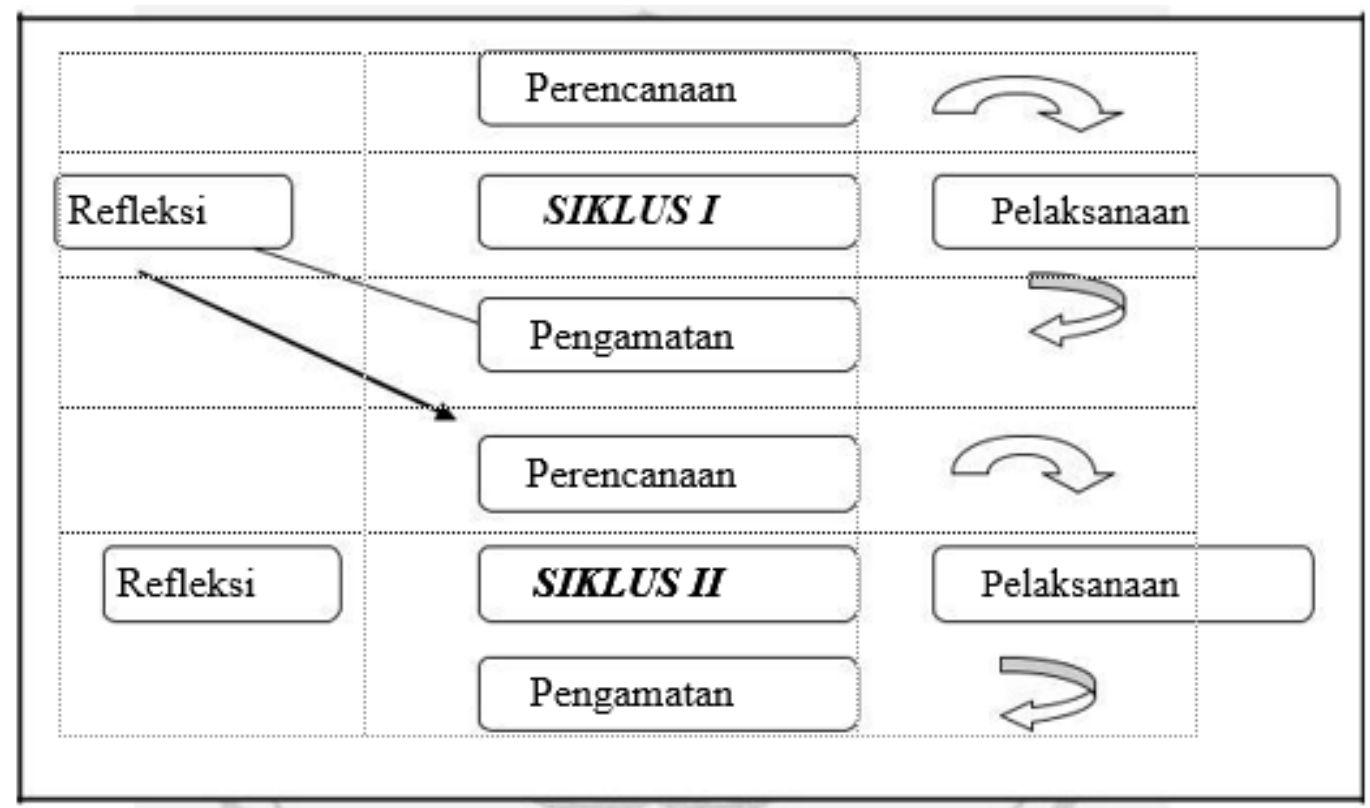

Gambar 9. Bagan tahapan PTK (Sumber: Suharsimi Arikunto dkk, 2006:16)

Dalam penelitian ini instrumen atau alat ukur yang digunakan adalah lembar penilian afektif, lembar penilaian psikomotorik, dan lembar penilaian kognitif. Adapun instrumen masing-masing aspek yang digunakan dalam penelitian tindakan kelas ini adalah sebagai berikut:

Tabel 2. Instrumen Penelitian

\begin{tabular}{|c|c|c|}
\hline \multicolumn{3}{|c|}{ Instrumen Aspek } \\
\hline Kognitif & Afektif & Psikomotorik \\
\hline $\begin{array}{l}\text { Memahami teknik dasar permainan } \\
\text { bulutangkis: } \\
\text { a. Servis } \\
\text { b. Lob }\end{array}$ & $\begin{array}{l}\text { a. Disiplin dalam bermain } \\
\text { b. Mau melakukan kerja sama tim } \\
\text { c. Semangat } \\
\text { d. Menghormati lawan } \\
\text { e. Sportif }\end{array}$ & $\begin{array}{l}\text { Mengusai teknik } \\
\text { bulutangkis: } \\
\text { a. Servis } \\
\text { b. Pukulan lob }\end{array}$ \\
\hline
\end{tabular}

Refleksi merupakan uraian tentang prosedur analisis terhadap hasil penelitian dan refleksi berkaitan dengan proses dan dampak tindakan yang dilaksanakan serta kriteria dan rencana bagi siklus berikutnya. Prosentase indikator pencapain keberhasilan penelitian pada tabel berikut:

Tabel 3. Rambu-rambu Hasil Analisis

\begin{tabular}{cll}
\hline Pencapaian Tujuan & \multicolumn{1}{c}{ Kualifikasi } & \multicolumn{1}{c}{ Tingkat Keberhasilan Pembelajaran } \\
\hline $85-100 \%$ & Sangat Baik & Berhasil \\
$65-84 \%$ & Baik & Berhasil \\
$55-64 \%$ & Cukup & Tidak Berhasil \\
$0-54 \%$ & Kurang & Tidak Berhasil \\
\hline
\end{tabular}

(Zainal Aqib, 2011: 53).

Tabel 4. Kriteria Ketuntasan Mininal Belajar Penjasorkes

$\begin{array}{cc}\text { Kriteria Ketuntasan } & \text { Kualifikasi } \\ \geq 78 & \text { Tuntas } \\ <78 & \text { Tidak Tuntas }\end{array}$

Berdasarkan hasil analisis ataupun refleksi pada siklus I dan II terhadap aktivitas dan hasil belajar siswa, maka peneliti akan menyimpulkan apakah hipotesis tindakan tercapai atau tidak. Jika aktivitas belajar dan hasil belajar siswa sesuai atau melampaui indikator keberhasilan, maka penerapan modifikasi alat bantu 
pembelajaran bokortasko dapat diterapkan untuk meningkatkan hasil belajar permainan bulutangkis pada siswa SMP.

\section{HASIL DAN PEMBAHASAN \\ Siklus I}

Pada siklus I hasil belajar kognitif yang berkaitan dengan pemahaman pembelajaran bokortasko yang telah diberikan kepada siswa melalui lembar tes memperoleh nilai rata-rata 7,8. Pada siklus I yang memperoleh nilai kognitif sangat baik adalah 5 siswa, kategori baik dengan jumlah 15 siswa,dan kategori cukup dengan jumlah 5 siswa. Secara rinci digambarkan sebagai berikut: rata-rata soal nomor satu sebanyak $68 \%$, soal nomor dua sebanyak $88 \%$, soal nomor tiga sebanyak $73 \%$, soal nomor empat sebanyak $88 \%$, soal nomor lima sebanyak $72 \%$, soal nomor enam sebanyak $80 \%$, soal nomor tujuh sebanyak $76 \%$, dan soal nomor delapan sebanyak $80 \%$, soal nomor sembilan sebanyak $84 \%$, dan soal nomor 10 sebanyak $68 \%$, sehingga jumlah rata-rata pemahaman siswa terhadap pembelajaran bulutangkis melalui kuesioner yang diberikan adalah $78 \%$ (baik).

Tabel 5. Data hasil belajar kognitif siswa pada siklus I

\begin{tabular}{|c|c|c|c|}
\hline No & Keterangan & Jumlah siswa & Presentase \\
\hline 1. & Sangat Baik & 5 & $20 \%$ \\
\hline 2. & Baik & 15 & $60 \%$ \\
\hline 3. & Cukup & 5 & $20 \%$ \\
\hline 4. & Kurang & - & - \\
\hline
\end{tabular}

Hasil belajar afektif dengan menggunakan modifikasi pembelajaran bulutangkis pada siklus I dapat dilihat pada tabel berikut ini:

Tabel 6. Data hasil belajar afektif siswa pada siklus I

\begin{tabular}{llcc} 
No & \multicolumn{1}{c}{ Keterangan } & Jumlah siswa & Presentase \\
\hline 1. & Sangat Baik & 2 & $8 \%$ \\
2. & Baik & 23 & $92 \%$ \\
3. & Cukup & - & - \\
4. & Kurang & - & - \\
\hline
\end{tabular}

Nilai rata-rata untuk ranah afeksi dengan beberapa penilaian yang telah diamati selama pembelajaran pada siklus I berlangsung, menunjukkan penilaian disiplin dalam bermain memperoleh rata-rata persentase sebanyak $77,6 \%$ bekerjasama memperoleh rata-rata persentase sebanyak $89,28 \%$, disiplin memperoleh ratarata sebanyak $80 \%$, semangat memperoleh rata-rata sebanyak $78,4 \%$, dan menghormati lawan memperoleh rata-rata sebanyak $80,8 \%$ sehingga rata-rata kelas mencapai $79,2 \%$ (baik). Sedangkan untuk hasil belajar psikomotorik siswa pada siklus I dapat dilihat pada tabel berikut ini:

Tabel 7. Data hasil belajar psikomotor siklus I

\begin{tabular}{llcc}
\multicolumn{1}{c}{ Keterangan } & Jumlah siswa & Presentase \\
\hline 1. & Sangat Baik & - & - \\
2. & Baik & 25 & $100 \%$ \\
3. & Cukup & - & - \\
4. & Kurang & - & - \\
\hline
\end{tabular}

Nilai rata-rata untuk ranah psikomotor dengan penilaian yang berkaitan dengan praktik permainan bokortasko yang telah diberikan pada siklus I menunjukkan penilaian saat servis kaki tidak menginjak garis sebanyak $72,8 \%$, penilaian saat servis ayunan tangan tidak terputus-putus sebanyak $76,8 \%$, penilaian bola masuk ke daerah lawan $76 \%$, penilaian gerakan tangan saat lob dari atas kepala sebanyak 78,4\%, sehingga jumlah rata-rata praktik permainan bokortasko adalah 76\% (baik). Rekap nilai akhir hasil belajar siswa pada siklus I dapat dilihat pada tabel berikut ini:

Tabel 8. Rekap nilai akhir hasil belajar siklus I 


\begin{tabular}{lcc} 
& Rata-rata & Keterangan \\
\hline KOGNITIF & 7,8 & Baik \\
AFEKTIF & 7,9 & Baik \\
PSIKOMOTORIK & 7,6 & Baik \\
N Nilai Akhir & 7,8 & Baik \\
\hline
\end{tabular}

Tabel 9. Jumlah ketuntasan hasil belajar siklus I

\begin{tabular}{cccc}
\hline No & Keterangan & Jumlah & Persentase \\
\hline 1. & Tuntas & 17 & $68 \%$ \\
2. & Tidak Tuntas & 8 & $32 \%$ \\
\hline
\end{tabular}

Untuk nilai akhir hasil belajar siswa pada siklus I diperoleh nilai rata-rata 7,8 dengan persentase ketuntasan klasikal sebesar 68\%. Jumlah siswa yang tuntas adalah 17 siswa (68\%) dan yang tidak tuntas adalah 8 siswa (32\%).

\section{Siklus II}

Untuk menilai hasil belajar kognitif siswa digunakan lembar tes yang sama pada siklus I. Hasil belajar kognitif siswa pada siklus II ini memperoleh nilai rata-rata yaitu 8,52. Pada siklus II yang memperoleh nilai kognitif sangat baik adalah 18 siswa (72\%), kategori baik dengan jumlah 7 siswa (28\%), kategori cukup dan kurang tidak ada. Secara rinci dijabarkan sebagai berikut: rata-rata soal nomor satu sebanyak $84 \%$, soal nomor dua sebanyak $96 \%$, soal nomor tiga sebanyak $92 \%$, soal nomor empat sebanyak $92 \%$, soal nomor lima sebanyak $84 \%$, soal nomor enam sebanyak $96 \%$, soal nomor tujuh sebanyak $84 \%$, dan soal nomor delapan sebanyak $84 \%$, soal nomor sembilan sebanyak $100 \%$, dan soal nomor 10 sebanyak $88 \%$, sehingga jumlah rata-rata pemahaman siswa terhadap pembelajaran bulutangkis melalui kuesioner yang diberikan adalah $90 \%$ (Sangat baik).

Tabel 10. Data hasil belajar kognitif siswa pada siklus II

\begin{tabular}{llcc}
\hline No & \multicolumn{1}{c}{ Keterangan } & Jumlah siswa & Presentase \\
\hline 1. & Sangat Baik & 18 & $72 \%$ \\
2. & Baik & 7 & $28 \%$ \\
3. & Cukup & - & - \\
4. & Kurang & - & - \\
\hline
\end{tabular}

Untuk menilai hasil belajar afektif dan psikomotorik siswa pada siklus II digunakan lembar observasi yang sama seperti pada siklus I. Hasil belajar afektif siswa pada siklus II dapat dilihat pada tabel berikut ini:

Tabel 11. Data hasil belajar afektif siswa pada akhir siklus II

\begin{tabular}{clcc}
\hline No & \multicolumn{1}{c}{ Keterangan } & Jumlah siswa & Presentase \\
\hline 1. & Sangat Baik & 10 & $40 \%$ \\
2. & Baik & 15 & $60 \%$ \\
3. & Cukup & - & - \\
4. & Kurang & - & - \\
\hline
\end{tabular}

Nilai rata-rata untuk ranah afeksi dengan beberapa penilaian yang telah diamati selama pembelajaran pada siklus II berlangsung, menunjukkan penilaian disiplin dalam bermain memperoleh rata-rata persentase sebanyak $79,2 \%$, bekerjasama memperoleh rata-rata persentase sebanyak $83,2 \%$, semangat memperoleh rata-rata sebanyak $83,2 \%$, menghormati lawan memperoleh rata-rata sebanyak $74,4 \%$, sehingga rata-rata kelas mencapai $82,4 \%$ (baik). Untuk hasil belajar psikomotorik siswa pada siklus II dapat dilihat pada tabel berikut ini:

Tabel 12. Data hasil belajar psikomotorik siswa pada akhir siklus II

\begin{tabular}{clcc}
\hline No & \multicolumn{1}{c}{ Keterangan } & Jumlah siswa & Presentase \\
\hline 1. & Sangat Baik & 10 & $40 \%$ \\
2. & Baik & 15 & $60 \%$ \\
3. & Cukup & - & - \\
4. & Kurang & - & - \\
\hline
\end{tabular}


Nilai rata-rata untuk ranah psikomotor dengan penilaian yang berkaitan dengan praktik permainan bokortasko yang telah diberikan pada siklus II menunjukkan penilaian saat servis kaki tidak menginjak garis sebanyak $88 \%$, penilaian saat servis ayunan tangan tidak terputus-putus sebanyak $84,8 \%$, penilaian bola masuk ke daerah lawan $74,4 \%$, penilaian gerakan tangan saat lob dari atas kepala sebanyak $78,4 \%$, sehingga jumlah rata-rata praktik permainan bokortasko adalah $81 \%$ (baik). Untuk nilai akhir hasil belajar siswa pada siklus II dapat dilihat pada tabel berikut ini:

Tabel 13. Rekap nilai akhir hasil belajar siklus II

\begin{tabular}{|c|c|c|}
\hline \multirow{2}{*}{ Nilai } & \multicolumn{2}{|c|}{ SIKLUS II } \\
\hline & Rata-Rata & Keterangan \\
\hline KOGNITIF & 9 & Sangat Baik \\
\hline AFEKTIF & 8,5 & Sangat Baik \\
\hline PSIKOMOTORIK & 8,1 & Baik \\
\hline$\sum$ Nilai Akhir & 8,5 & Sangat Baik \\
\hline
\end{tabular}

Tabel 14. Jumlah ketuntasan hasil belajar siklus II

\begin{tabular}{lllll}
\hline No & & Keterangan & Jumlah & Persentase \\
\hline 1 & Tuntas & 22 & & $88 \%$ \\
2 & Tidak Tuntas & 3 & $12 \%$ & \\
\hline
\end{tabular}

Dari tabel di atas diperoleh bahwa nilai akhir hasil belajar siswa pada siklus II dengan jumlah siswa yang tuntas adalah 22 siswa dan yang tidak tuntas adalah 3 siswa dengan persentase ketuntasan klasikal sebesar $88 \%$ dan nilai rata-rata 8,5 .

\section{Pembahasan}

\section{Siklus I}

Pada saat pelaksanaan siklus I, menunjukkan adanya peningkatan hasil belajar siswa dari pembelajaran yang sebelumnya, hal ini dikarenakan siswa merasa senang dan tertarik terhadap permainan bokortasko. Ketertarikan siswa terhadap permainan bokortasko dikarenakan permainan ini merupakan hal baru yang tidak pernah mereka ketahui sebelumnya. Dengan adanya penggunaan bola berekor, membuat siswa merasa bersemangat untuk terus memukul bola, karena bola hasil pukulan yang melayang di udara akan terlihat indah seperti komet yang terbang. Hal ini juga menjadi faktor keberhasilan adanya peningkatan hasil belajar siswa.

Namun demikian, pada siklus I masih perlu adanya perbaikan guna untuk peningkatan hasil belajar pada siklus berikutnya. Alasan dilakukannya perbaikan karena dalam pembelajaran terlihat ada beberapa siswa yang masih merasa kesulitan untuk memasukkan bola ke dalam target sasaran, karena sasaran yang digunakan untuk tempat masuknya bola hanya diam di daerah lapangan lawan bagian belakang.

Dengan melihat hasil belajar siklus I diatas menunjukkan bahwa indikator keberhasilan yang ditetapkan belum tercapai. Hal ini disebabkan karena siswa dalam proses pembelajaran masih ada beberapa siswa yang sibuk sendiri dan kurang memperhatikan pelajaran. Di lapangan juga masih terdapat siswa yang terlihat pasif yaitu siswa masih merasa takut untuk bertanya dan mengungkapkan pendapatnya terhadap materi yang disampaikan. Di samping itu masih ada siswa yang terlihat menggunakan alat modifikasi untuk main-main, siswa tidak memanfaatkan waktu dengan baik sehingga waktu pembelajaran habis terbuang.

Berdasarkan uraian di atas, maka masih perlu diadakan perbaikan proses pembelajaran pada siklus berikutnya. Perbaikan-perbaikan yang dilakukan antara lain memperbaiki rencana pembelajaran dengan memberikan variasi permainan sehingga siswa lebih aktif bergerak, guru harus memotivasi siswa untuk aktif bekerjasama dengan temannya pada saat proses kegiatan pembelajaran.

\section{Siklus II}

Sesuai dengan hasil refleksi pada siklus I, maka pada siklus II ini diadakan perbaikan guna meningkatkan hasil belajar pada siswa. Perbaikan yang dilakukan adalah mengubah peraturan permainan dengan mengubah formasi serta menambah jumlah pemain, menambah jumlah bola berekor, dan mengubah bentuk lapangan. 
Dari hal ini dapat dilihat bahwa siswa merasa lebih tertantang lagi dan merasa senang untuk melakukan pembelajaran bulutangkis melalui perbaikan modifikasi alat bantu pembelajaran bokortasko yang lebih mudah dan menarik untuk dilakukan oleh siswa, sehingga dengan adanya perubahan peraturan lebih meningkatkan kerjasama tim, siswa merasa antusias dan lebih mudah untuk mempelajari permainan bulutangkis, sehingga akan ada peningkatan hasil belajar baik dari aspek afektif, kognitif, dan psikomotorik.

Tercapainya ketuntasan hasil belajar baik kognitif, afektif, dan psikomotorik pada siklus II dikarenakan semakin meningkatnya keaktifan siswa dalam proses pembelajaran baik pada saat pembelajaran maupun permainan, siswa telah dapat bekerjasama dengan temannya dalam pembelajaran maupun dalam pertandingan permainan tim, oleh karena itu tugas yang diberikan dapat diselesaikan dengan baik.

Tabel 15. Perbandingan Persentase Hasil Belajar Siswa Tiap Siklus

\begin{tabular}{llllll}
\hline \multicolumn{1}{c}{ Siklus } & Nilai Afektif & Nilai Kognitif & Nilai Psikomotorik & Nilai Akhir & Ketuntasan Klasikal \\
\hline Pertama & $79 \%$ & $78 \%$ & $76 \%$ & $78 \%$ & $17(68 \%)$ \\
Kedua & $82 \%$ & $90 \%$ & $81 \%$ & $85 \%$ & $22(88 \%)$ \\
Peningkatan & $3 \%$ & $12 \%$ & $5 \%$ & $7 \%$ & $5(20 \%)$ \\
\hline
\end{tabular}

Dari tabel di atas dapat dilihat bahwa dari kedua siklus yang telah dilakukan, ternyata penerapan pembelajaran dengan memodifikasi permainan bulutangkis dapat meningkatkan hasil belajar siswa.

\section{SIMPULAN}

Dari hasil penelitian yang dilaksanakan peneliti selama 2 siklus diperoleh hasil bahwa melalui modifikasi alat bantu pembelajaran bulutangkis dapat meningkatkan hasil belajar siswa kelas VIII A SMP Negeri 18 Kota Jambi tahun pelajaran 2017. Peningkatan hasil belajar dapat dilihat dari ketuntasan belajar klasikal (kognitif, afektif, psikomotorik) dari siklus I ke siklus II.

Hasil belajar kognitif mengalami peningkatan. Pada siklus I nilai rata-rata tes tertulis 7,8 dan pada siklus II nilai rata-rata tes tertulis 9, jadi hasil belajar kognitif dari siklus I ke siklus II mengalami peningkatan sebesar $15,4 \%$. Hasil belajar afektif juga mengalami peningkatan. Nilai rata-rata afektif pada siklus I adalah 7,9, dan nilai rata-rata afektif pada siklus II adalah 8,2. Jadi hasil belajar afektif dari siklus I ke siklus II mengalami peningkatan sebesar 3,8\%. Hasil belajar psikomotorik juga mengalami peningkatan, pada siklus I nilai rata-rata psikomotorik adalah 7,6 dan pada siklus II adalah 8,1. Jadi hasil belajar psikomotorik dari siklus I ke siklus II mengalami peningkatan sebesar 6,6\%.

Ketuntasan klasikal pada siklus I adalah $68 \%$ dengan nilai rata-rata 7,8 dan ketuntasan klasikal pada siklus II adalah $88 \%$ dengan nilai rata-rata 8,5. Sehingga hasil belajar secara keseluruhan dari siklus I ke siklus II mengalami peningkatan sebesar $20 \%$.

\section{DAFTAR PUSTAKA}

Adang Suherman dan Yoyo Bahagia. 2000. Dasar-Dasar Penjaskes. Jakarta: Depdiknas — 2000. Prinsip-Prinsip Pengembangan dan Modifikasi Cabang Olahraga. Depdikbud

Agus Kristiyanto. 2010. Penelitian Tindakan Kelas. Surakarta: UNS press

Catharina Tri Anni dan Achmad Rifai RC. 2007. Psikologi Belajar. Semarang: UPT UNNES Press

Grice, Tony. 1999. Bulutangkis Petunjuk Praktis untuk Pemula dan Lanjut, Jakarta: PT Raja Grafindo Persada

Herman Subarjah. 2004. Pendekatan Ketrampilan Taktis dalam Pembelajaran Bulu Tangkis. Jakarta: Depdiknas

H. Abdulkadir Ateng. 1992. Asas dan Landasan Pendidikan Jasmani. Jakarta: Depdikbud

http://id.wikipedia.org/wiki/Bulutangkis (accesed 07.46/26/03/2013)

Icuk Sugiyarto. 2004. Total Badminton. Solo: Cv Setyaki Eka Anugerah.

Nadisah. 1992. Pengembangan Kurukulum Pendidikan Jasmani dan Kesehatan.Bandung : Depdikbud

Permendiknas No 23. 2006. Standar Kompetensi Kelulusan Untuk Satuan Pendidikan Dasar dan Menengah. Jakarta: Depdiknas

Slameto. 2010. Belajar dan Faktor-Faktor Yang Mempengaruhinya. Jakarta: Rineka Cipta 
Suharsimi Arikunto. 2006. Prosedur Penelitian Suatu Pendekatan Praktik. Jakarta : PT Rineka Cipta Suharsimi Arikunto.. 2009. Penelitian Tindakan Kelas. Jakarta: PT Bumi Aksara

Sugiyanto dan Sudjarwo. 1993.Perkembangan dan Belajar Gerak, Jakarta: depdiknas.

Sukintaka. 1992. Teori Bermain Penjaskes, Jakarta: Depdiknas.

Supandi. 1992. Strategi Belajar Mengajar Pendidikan Jasmani dan Kesehatan. Jakarta: Depdikbud Syaiful Bahri Djamarah. 2010. Guru dan Anak Didik Dalam Interaksi Edukatif. Jakarta: Rineka Cipta Zainal Aqib. 2011. Penelitian Tindakan Kelas. Bandung: Yrama Widya 